\title{
Treatment of Metastatic Castration-resistant Prostate Cancer: Are PARP Inhibitors Shifting the Paradigm?
}

\author{
NAOHIRO FUJIMOTO ${ }^{1}$, KENICHI HARADA ${ }^{2}$, MASAKI SHIOTA ${ }^{3}$, IKKO TOMISAKI ${ }^{1}$, AKINORI MINATO ${ }^{1}$, \\ YUJIRO NAGATA ${ }^{1}$, RIEKO KIMURO ${ }^{1}$, MIRII HARADA ${ }^{1}$ and MASATO FUJISAWA ${ }^{2}$ \\ ${ }^{1}$ Department of Urology, University of Occupational and Environmental Health, Kitakyushu, Japan; \\ ${ }^{2}$ Department of Urology, Kobe University Graduate School of Medicine, Kobe, Japan; \\ ${ }^{3}$ Department of Urology, Graduate School of Medical Sciences, Kyushu University, Fukuoka, Japan
}

\begin{abstract}
Remarkable developments in the treatment of metastatic castration-resistant prostate cancer ( $m C R P C)$ have been achieved over the past decade. Although targeting the novel androgen receptor axis and using chemotherapeutic agents have improved survival, $m C R P C$ is still a lethal disease. A better molecular characterization of cancer resulted in the determination of the important role of homologous recombination repair (HRR) genes in cancer development, and poly (ADP-ribose) polymerase (PARP) is one of the most attractive therapeutic targets. Recent clinical studies have demonstrated that PARP inhibitors significantly improve oncological outcomes in patients with $\mathrm{mCRPC}$ harboring BRCA mutations, and PARP inhibitors are becoming a standard of care for these patients. However, not only PARP inhibitors, but also chemotherapeutic agents such as platinum agents, taxanes, and radium-223 are active in HRR gene mutation carriers, and platinum sensitivity may predict the efficacy of PARP inhibitors for $m C R P C$. The combination of PARP inhibitors with other anti-cancer agents may overcome resistance mechanisms against PARP inhibitors and lead to survival benefits. Appropriate treatment sequences and combinations may change the therapeutic landscape of DNA repair deficient $m C R P C$.
\end{abstract}

Prostate cancer is the most frequently diagnosed cancer in 105 of 185 countries (1), and the number of patients has

This article is freely accessible online.

Correspondence to: Naohiro Fujimoto, MD, PhD, Department of Urology, University of Occupational and Environmental Health, 11 Iseigaoka, Yahatanishi-ku, Kitakyushu 807-8556, Japan. Tel: +81 936917446, Fax: +81 936038724, e-mail: n-fuji@med.uoeh-u.ac.jp

Key Words: Castration-resistant prostate cancer, homologous recombination, DNA repair, PARP inhibitor, platinum, review. been increasing worldwide, particularly in Asia and developing countries (2). Although localized prostate cancer has a favorable prognosis by definitive treatment such as surgery and radiation therapy, metastatic disease has a poor prognosis with five-year relative survival rate of only $30 \%$ (3). Despite the initial favorable response to androgen deprivation therapy, the vast majority of metastatic prostate cancers eventually progress to fatal disease, castrationresistant prostate cancer (CRPC), by overcoming low circulating levels of androgens (4).

Large-scale phase III clinical trials using novel agents for prostate cancer have demonstrated the improvement of oncological outcomes, and the treatment strategy of mCRPC has been dramatically changing. In 2004, the TAX327 trial showed prolonged overall survival (OS) in patients with metastatic CRPC (mCRPC) using the chemotherapeutic agent docetaxel. This was the first phase III trial to demonstrate a statistically significant prolongation of OS for mCRPC. Following this landmark study, the androgen receptor axis-targeted agents (ARATs) such as abiraterone acetate, enzalutamide, alpha-emitter radium-223, and immunotherapeutic sipleucel $\mathrm{T}$ demonstrated survival benefits for men with mCRPC (5). In fact, these agents improved OS by three-four months and OS for men with mCRPC was shorter than 3 years and still unfavorable (6). According to recent developments in molecular biology, precision medicine has been introduced, and molecular profiling can be used to select effective pharmaceuticals for each individual. Advances in the molecular characterization of cancer resulted in the determination of the important role of homologous recombination repair (HRR) genes in cancer development and progression, and poly (ADP-ribose) polymerase (PARP) is one of the most attractive therapeutic targets. PARP plays a pivotal role in single-strand DNA break repair via homologous recombination (7). Thus, in cells with pathogenic mutations in double-strand DNA repair 
genes such as BRCA1 and 2, ATM, and PALB2, PARP is required for survival and a PARP inhibitor is able to induce cell death.

\section{Efficacy of PARP Inhibitors for mCRPC}

PARP inhibitors have been approved for the treatment of breast, ovarian, and pancreatic cancers harboring $B R C A$ mutations. PARP inhibitors have also shown promising efficacy in patients with mCRPC $(8,9)$.

The PROfound trial was a landmark phase III HRR alteration-driven study in MCRPC that evaluated for the first time the efficacy of the PARP inhibitor olaparib for $\mathrm{mCRPC}$ harboring HRR gene mutations (Table I) (8). This study enrolled mCRPC patients with progression while on ARATs and/or taxanes, such as docetaxel and cabazitaxel. All men had alterations in one or more HRR genes. Cohort $A(n=245)$ patients had at least one mutation in $B R C A 1, B R C A 2$, or $A T M$, whereas cohort B $(\mathrm{n}=142)$ patients had mutations in 12 other HRR genes. Patients were randomized to olaparib or the physician's choice of abiraterone or enzalutamide (control arm). In cohort $A$, this study met the primary endpoint of radiological progression-free survival (rPFS) [median 7.4 vs. 3.6 months, hazard ratio (HR) for progression or death: $0.34,95 \%$ confidence interval $(C I)=0.25-0.47]$. The objective response rate and time to pain progression were also better in the olaparib arm compared with the control arm. In cohort A, the median OS for patients treated with olaparib was significantly longer than that for those who received a control therapy (19.1 months vs. 14.7 months, $\mathrm{HR}=0.69 ; 95 \% \mathrm{CI}=0.50-0.97, p=0.02)$ (10). In patients without $B R C A$ mutations, olaparib was not effective in terms of rPFS, radiological response, or OS $(8,10,11)$.

The efficacy of rucaparib, another PARP inhibitor, was evaluated in men with $\mathrm{mCRPC}$ harboring a BRCA1/2 mutation in the phase II TRITON2 study (9). The objective response rate (ORR), the primary endpoint, was 43.5\% (27 of 62 patients; $95 \% \mathrm{CI}=31.0 \%-56.7 \%$ ), and the prostate specific antigen (PSA) response rate was $54.8 \%$ (63 of 115 patients, $95 \% \mathrm{CI}=45.1 \%-64.1 \%$ ). These results indicate the efficacy of rucaparib in mCRPC patients with $B R C A$ mutations.

Olaparib and rucaparib are approved by the U.S. Food and Drug Administration (FDA) for patients with germline or somatic HRR gene-mutated mCRPC, who progressed following prior treatment with ARATs and/or taxane-based chemotherapy (12). The European Medicines Agency (EMA) approved olaparib for $B R C A$ mutation carriers, and the updated AUA/ASTRO/SUO (13) and EAU guidelines (14) recommend PARP inhibitors for patients with HHR gene mutations. Other PARP inhibitors such as niraparib and talazoparib, were also shown to have anticancer activity in mCRPC patients with $B R C A$ mutations and many clinical trials are evaluating efficacy and safety of PARP inhibitors for mCRPC (15). Treatment using a PARP inhibitor is becoming a standard of care for patients with DNA repairdeficient prostate cancer.

\section{Are PARP Inhibitors Going to Dramatically Change the Treatment Landscape of mCRPC?}

Frequency of BRCA mutations in prostate cancer. Germline mutations in HHR, BRCA1, and BRCA2 genes were noted in $11.8 \%, 0.87 \%$, and $5.35 \%$, respectively, of 692 men with metastatic prostate cancer (16). These mutations are thought to affect DNA repair efficiency (17). More recent analyses revealed that germline pathogenic and likely pathogenic variants of $B R C A 1$ and $B R C A 2$ were $0.8 \%-0.9 \%$ and $3.4 \%$ $4.8 \%$, respectively, in African American and Caucasian men with metastatic prostate cancer $(18,19)$. Pathogenic mutations are generally more frequently somatic than germline. The prevalence of somatic BRCA1/2 mutations in CRPC was $14 \%-16 \%(20,21)$. In bone and soft tissue biopsy samples from mCRPC, somatic HRR and BRCA2 gene alterations were observed in $22.7 \%$ (34/150) and $12.7 \%(19 / 150)$ of patients, respectively (20). In the PROfound prospective study, only 141 of $2792(5.1 \%)$ patients were found to carry a somatic and germline $B R C A$ mutation, a prevalence that was less than that reported in previous studies (8).

The prevalence of HRR gene mutations may be different in selected populations. Some studies have demonstrated that HRR gene mutations are associated with higher Gleason scores, advanced stage, and poor oncological outcomes after treatment $(16,22-24)$. The first prospective trial PROREPAIR-B showed that germline BRCA mutations were an independent poor prognostic factor for cancer-specific survival (17.4 in BRCA2 mutation vs. 33.2 months in nonmutated patients, $p=0.027$ ) (25). More recently, Annala et al. (26) also demonstrated that HRR gene mutations were more frequently in men with metastatic castration-sensitive prostate cancer with aggressive and poor prognosis features than the unselected prostate cancer patient group (29\% vs. $9 \%$ of patients, $p<0.0001)$. In this population with higher HRR defects, however, the frequency of germline and/or somatic BRCA1/2 mutations was limited and observed in $0 \%$ and $11 \%$ of patients, respectively. These studies indicate an association between HRR deficiency and worse clinical features. However, conflicting results have been reported. For example, Mateo et al. (27) reported no difference in the PFS of patients treated with ARATs between patients carrying a germline HRR mutation and those who did not. Therefore, the association between HRR gene mutations and clinical features remains to be determined.

Kwon et al. (19) also suggested ethnic differences in patients with germline HRR gene mutations. African American men with prostate cancer were more likely to have germline pathogenic and likely pathogenic mutations of 


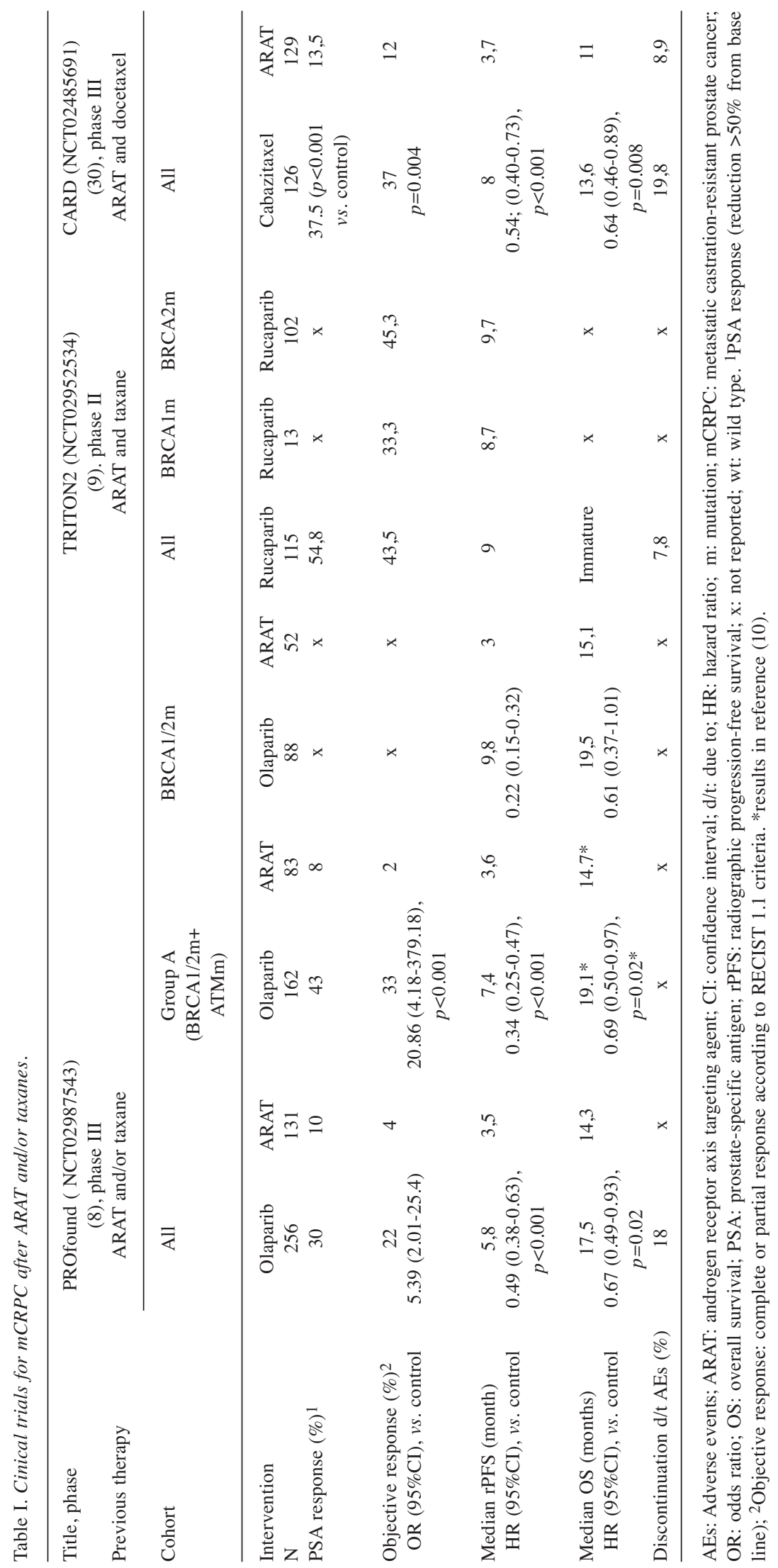


Table II. Antitumor activity of platinum-based chemotherapy in prostate cancer patients with or without HRR mutations.

\begin{tabular}{|c|c|c|c|c|c|c|c|c|c|c|c|}
\hline \multirow{2}{*}{$\begin{array}{l}\text { Authors, year } \\
\text { Cohort }\end{array}$} & \multirow{2}{*}{$\begin{array}{c}\text { Pomerantz et al } \\
\text { (40), } 2017 \\
\text { BRCA2m }\end{array}$} & \multicolumn{4}{|c|}{ Schmid et al. (41), 2020} & \multicolumn{3}{|c|}{ Mota et al. (42), 2020} & \multicolumn{3}{|c|}{ Sloolbeek et al. (43), 2021} \\
\hline & & BRCA2wt & HRRm & $\mathrm{BRCA} 2 \mathrm{~m}$ & HRRwt & HRRm & $\mathrm{BRCA} 2 \mathrm{~m}$ & HRRwt & HRRm & $\mathrm{BRCA} 2 \mathrm{~m}$ & HRRwt \\
\hline $\mathrm{N}$ & 8 & 133 & 80 & 44 & 98 & 16 & 6 & 48 & 14 & 7 & 16 \\
\hline PSA response $(\%)^{1}$ & 75 & 17 & 47,1 & 63,9 & 36,1 & 50 & 67 & 13 & 71,4 & 100 & 31,3 \\
\hline Objective response $(\%)^{2}$ & $\mathrm{x}$ & $\mathrm{x}$ & 48,3 & 50 & 31,3 & $\mathrm{x}$ & $\mathrm{x}$ & $\mathrm{x}$ & 58,4 & 100 & 21,4 \\
\hline $\begin{array}{l}\text { Time on treatment } \\
\text { (median, months) }\end{array}$ & 15 (weeks) & 12 (weeks) & 3,4 & 7,1 & 2,8 & 3 & 3,9 & 1,6 & $\mathrm{x}$ & $\mathrm{x}$ & $\mathrm{x}$ \\
\hline OS (median, months) & 18,9 & 9,5 & 14 & 15 & 9,2 & 9 & 8,4 & 7,8 & 8,4 & 21 & 7 \\
\hline
\end{tabular}

HRR: Homologous recombination repair; HR: hazard ratio; m: mutation; OS: overall survival; PFS: progression-free survival; rPFS: radiographic progression-free survival; x: not reported; wt: wild type. ${ }^{1} \mathrm{PSA}$ response (reduction $>50 \%$ from base line); ${ }^{2}$ Objective response: complete or partial response according to RECIST 1.1 criteria.

BRCAl than Caucasian men (18). These studies raise the possibility that the frequency of $B R C A$ mutations may be higher in selected populations than in unselected populations. $B R C A$ mutations, however, are infrequent and have been found in a small population of patients with prostate cancer.

In addition to the limited prevalence of $B R C A$ mutations, not all patients harboring $B R C A$ mutations benefit from PARP inhibitors. The PROfound trial revealed that PSA and objective response rate to olaparib in patients in cohort A (alteration in $B R C A 1 / 2$ or $A T M$ ) were $43 \%$ and $33 \%$, respectively (8). PARP inhibitors, therefore, may be beneficial for a limited patient population with mCRPC.

Control arm in the landmark PROfound trial. The patients in the control arm of the PROfound trial received alternative ARAT after another ARAT; for example, they were switched from abiraterone to enzalutamide, and vice versa. The rPFS, objective response, and PSA response rate in the control arm were only 3.5 months, $4 \%$, and $10 \%$, respectively (8). Retrospective and prospective studies have indicated that cross-resistance between ARATs and the treatment efficacy of alternative ARATs is very limited (2830). The CARD trial prospectively compared the efficacy and safety of cabazitaxel and alternative ARAT for men with mCRPC (Table I) (30). In the alternative ARAT arm, median rPFS, PSA response, and objective tumor response rate were only 3.7 months, $13.5 \%$, and $11.5 \%$, respectively. After progression on ARATs, most patients receive docetaxel in the real world (31). Although the PROfound trial showed the superiority of olaparib compared to the control arm of ARAT, this control arm may be suboptimal. PARP inhibitors should be compared with active and appropriate treatment for the individual patient. For example, the phase II clinical trial NCT04038502 is comparing the efficacy of carboplatin and olaparib in $B R C A$-deficient mCRPC.
Activity of platinum, taxane, and radium-223 in BRCA mutation carriers. BRCA mutation carriers are sensitive not only to PARP inhibitors, but also to platinum-based chemotherapy. Platinum binds directly to DNA, induces DNA double-strand breaks, and may be more effective in $B R C A$ pathogenic mutation carriers. In ovarian, pancreatic, and breast cancers, $B R C A$ carriers are more sensitive to platinum-based chemotherapy than non-carriers (32-37).

$B R C A$-associated prostate cancer may also be sensitive to platinum-based chemotherapy. Cisplatin and carboplatin were shown to exert moderate activity in men with mCRPC $(38,39)$. Retrospective studies revealed that platinum-based chemotherapy was more effective in patients with mCRPC harboring BRCA mutations (Table II) (40-43). The PSA responses ( $>50 \%$ decline) to platinum were $64 \%-100 \%$ and $17 \%-36 \%$ in BRCA2 mutation carriers and non-carriers, respectively. Radiographic response rate and OS were also better in BRCA2 mutation carriers compared to non-carriers. Some case series showed exceptional efficacy of carboplatin for mCRPC with DNA repair defects such as BRCA2 and ATM mutations $(44,45)$. An in vivo study demonstrated that suppression of functional BRCA2 increased, but overexpression reduced the sensitivity of prostate cancer cells to carboplatin (40) These studies suggest that platinum is active in men with HRR gene alterations, including $B R C A$ mutations.

To date, there are no data suggesting the superiority of a PARP inhibitor for HRR mutation carriers compared to platinum. In a small but real-world study, the efficacy of olaparib and carboplatin was identical for mCRPC with $B R C A$ alterations (46). In this study, PFS for men with $B R C A 2$ alterations who received olaparib and carboplatin was 4.9 months and 5.4 months, respectively $(\mathrm{HR}=0.71$, $95 \% \mathrm{CI}=0.45-1.11, p=0.13)$. No difference in PFS was also observed among men with BRCA2, BRCA1, or ATM alterations treated with olaparib and carboplatin (3.8 months 
vs. 3.6 months, $\mathrm{HR}=0.8095 \% \mathrm{CI}=0.54-1.16, p=0.24)$. Taken together, platinum may have similar efficacy to PARP inhibitors and can be used for patients with HRR-mutated mCRPC. Clinical trials (NCT04038502, NCT03652493, NCT02598895, NCT02985021, and NCT03442556) are underway to assess the efficacy and safety of carboplatin with or without docetaxel for DNA repair-deficient mCRPC, and the results may provide promising clinical information.

HRR mutations have little impact on the efficacy of taxane chemotherapy. PFS of patients on docetaxel with and without HRR mutations was not significantly different $(\mathrm{HR}=0.86,95 \% \mathrm{CI}=0.61-1.20, p=0.37)$. PFS for patients with or without $B R C A$ mutations was also identical (HR=0.96, $95 \% \mathrm{CI}=0.64-1.43, p=0.83$ ) (27). The PSA response to taxanes was $57 \%$ and $42 \%$ in BRCA mutation carriers and non-carriers, respectively. In breast cancer patients, docetaxel had the same activity regardless of $B R C A 2$ mutation status (47). Therefore, taxanes are a valid option for patients with mCRPC, even though they have BRCA alterations.

Radium-223 may also be active in men with $B R C A$ mutations. Alpha particles cause double-strand DNA breaks (48), and cells harboring DNA repair gene defects may be more susceptible to radium-223. van der Doelen et al. treated mCRPC patients with radium-223 (49). Twenty-six were pathogenic HHR mutation carriers (HRR+), and 67 were noncarriers (HRR-). The OS, the primary endpoint, was better in the HRR+ than in the HRR- cohort (36.3 months vs. 17.0 months, HR=2.29, 95\% CI=1.21-4.32, $p=0.011)$. PRORADIUM (NCT02925702) is a prospective observational biomarker study of patients with mCRPC treated with radium-223. In this study, 14 germline HRR mutation (five $B R C A 2$, four $A T M$, one $B R C A 1$, four other genes) carriers and 161 non-carriers were included. A significantly greater decline in alkaline phosphatase at 12 weeks was observed in HRR gene mutation carriers than in non-carriers (75\% vs. $43 \%, p=0.036)$. OS was longer in HRR gene mutation carriers than in non-carriers, although the difference did not reach statistical significance (median 14.4 months $v s .10 .6$ months, $p=0.066$ ) (50). Taken together, not only PARP inhibitors, but also platinum, taxanes, and radium223 may be promising treatment options for DNA repairdeficient prostate cancer.

\section{Platinum Sensitivity Could be a Biomarker for Efficacy of a PARP Inhibitor}

For patients with breast, ovarian, and pancreatic cancers harboring $B R C A$ alterations, PARP inhibitors are used after chemotherapy. $B R C A$ mutations predict the response of ovarian and breast cancers to platinum $(51,52)$. Niraparib and olaparib are recommended as maintenance therapies after platinumbased chemotherapy only for platinum-sensitive cancer (53-55).

In ovarian cancer patients with $B R C A$ mutations, olaparib was more active in patients with platinum sensitivity than in others (56). In this study, platinum-sensitive and platinumresistant patients were defined as those who showed disease progression in more and less than 6 months, respectively, after their last platinum chemotherapy. Platinum-refractory disease was defined as disease progression during platinum-based chemotherapy. Complete or partial responses were noted in $46.2 \%, 33.5 \%$, and $0 \%$ of patients in the platinum-sensitive, platinum-resistant, and platinum-refractory groups, respectively. The clinical benefit rates determined by radiographic and tumor marker responses were $69.2 \%, 45.8 \%$, and $23.1 \%$ in the platinum-sensitive, -resistant, and -refractory groups, respectively. These results suggest that platinuminsensitive cancer may be less sensitive to olaparib, and platinum sensitivity may be a useful biomarker for predicting the efficacy of olaparib in mCRPC with $B R C A$ mutations.

\section{Future Perspectives}

Future studies may identify pharmacogenomic biomarkers that predict the efficacy of pharmaceuticals for HRR-deficient mCRPC. The expected results will improve the efficacy of PARP inhibitors. As the positive rate of the BRCA test is low among the unselected population, it is mandatory to identify patient groups with a higher frequency of HRR deficiency. Although the prognostic role of HRR gene mutations has not been determined yet, aggressive prostate cancer may be a suitable candidate for $B R C A$ analysis because of the possibility of a higher rate of $B R C A$ mutations (56).

Not all $B R C A$ mutation carriers benefit from PARP inhibitors, and cancer cells harboring $B R C A$ mutations exert primary and acquired resistance to a PARP inhibitor. Combination with other anticancer agents may overcome these resistance mechanisms. Many clinical trials investigating the efficacy of a combination of PARP inhibitors and ARATs, taxanes, molecular targeting, and immuno-oncology drugs for CRPC are ongoing (57) and show the efficacy of PARP inhibitors for mCRPC.

Platinum, taxanes, and radiopharmaceuticals are also active for mCRPC with BRCA mutations, and the clinical benefits of these agents should be determined.

\section{Conclusion}

PARP inhibitors are becoming the standard of care for mCRPC harboring HRR gene mutations. Clinical and molecular biomarkers that predict the patients who will benefit from PARP inhibitors should further improve treatment outcomes. DNA repair-deficient mCRPC patients respond not only to PARP inhibitors, but also to platinum, taxanes, and radium-223. Ongoing and future studies must determine which agent, either monotherapy or combination, is optimal for individual patients with mCRPC harboring HRR gene mutations. 


\section{Conflicts of Interest}

Masaki Shiota received honoraria from Janssen Pharmaceutical, AstraZeneca, and Astellas Pharma, and research funding support from Daiichi Sankyo. Other Authors report no conflicts of interest regarding this work.

\section{Authors' Contributions}

Naohiro Fujimoto conceived the presented idea and wrote the manuscript. Kenichi Harada, Masaki Shiota, Ikko Tomisaki, Akinori Minato, Yujiro Nagata, Rieko Kimuro, Mirii Harada collected and selected the references. Masato Fujisawa supervised the work. All Authors discussed, verified and approved the final version of the manuscript.

\section{Acknowledgements}

The Authors would like to thank Editage (www.editage.com) for English language editing.

\section{References}

1 Bray F, Ferlay J, Soerjomataram I, Siegel RL, Torre LA and Jemal A: Global cancer statistics 2018: GLOBOCAN estimates of incidence and mortality worldwide for 36 cancers in 185 countries. CA Cancer J Clin 68(6): 394-424, 2018. PMID: 30207593. DOI: 10.3322/caac.21492

2 Teoh JYC, Hirai HW, Ho JMW, Chan FCH, Tsoi KKF and Ng $\mathrm{CF}$ : Global incidence of prostate cancer in developing and developed countries with changing age structures. PLoS One 14(10): e0221775, 2019. PMID: 31647819. DOI: 10.1371/ journal.pone.0221775

3 Siegel RL, Miller KD and Jemal A: Cancer statistics, 2020. CA Cancer J Clin 70(1): 7-30, 2020. PMID: 31912902. DOI: $10.3322 /$ caac. 21590

4 Komura K, Sweeney CJ, Inamoto T, Ibuki N, Azuma H and Kantoff PW: Current treatment strategies for advanced prostate cancer. Int J Urol 25(3): 220-231, 2018. PMID: 29266472. DOI: 10.1111/iju.13512

5 Corfield J, Crozier J, Joshua AM, Bolton D and Lawrentschuk $\mathrm{N}$ : Understanding the role of new systemic agents in the treatment of prostate cancer. BJU Int 118 Suppl 3: 8-13, 2016. PMID: 27709828. DOI: 10.1111/bju.13633

6 EAU Guidelines: Prostate Cancer. Available at: https://uroweb. org/guideline/prostate-cancer/\#6_4 [Last accessed on August 2, 2021]

7 Bartkova J, Rezaei N, Liontos M, Karakaidos P, Kletsas D, Issaeva N, Vassiliou LV, Kolettas E, Niforou K, Zoumpourlis VC, Takaoka M, Nakagawa H, Tort F, Fugger K, Johansson F, Sehested M, Andersen CL, Dyrskjot L, Ørntoft T, Lukas J, Kittas C, Helleday T, Halazonetis TD, Bartek J and Gorgoulis VG: Oncogene-induced senescence is part of the tumorigenesis barrier imposed by DNA damage checkpoints. Nature 444(7119): 633-637, 2006. PMID: 17136093. DOI: 10.1038/nature05268

8 de Bono J, Mateo J, Fizazi K, Saad F, Shore N, Sandhu S, Chi KN, Sartor O, Agarwal N, Olmos D, Thiery-Vuillemin A, Twardowski P, Mehra N, Goessl C, Kang J, Burgents J, Wu W, Kohlmann A, Adelman CA and Hussain M: Olaparib for metastatic castration- resistant prostate cancer. N Engl J Med 382(22): 2091-2102, 2020. PMID: 32343890. DOI: 10.1056/NEJMoa1911440

9 Abida W, Patnaik A, Campbell D, Shapiro J, Bryce AH, McDermott R, Sautois B, Vogelzang NJ, Bambury RM, Voog E, Zhang J, Piulats JM, Ryan CJ, Merseburger AS, Daugaard G, Heidenreich A, Fizazi K, Higano CS, Krieger LE, Sternberg CN, Watkins SP, Despain D, Simmons AD, Loehr A, Dowson M, Golsorkhi T, Chowdhury $\mathrm{S}$ and TRITON2 investigators: Rucaparib in men with metastatic castration-resistant prostate cancer harboring a $B R C A 1$ or $B R C A 2$ gene alteration. J Clin Oncol 38(32): 3763-3772, 2020. PMID: 32795228. DOI: 10.1200/JCO.20.01035

10 Hussain M, Mateo J, Fizazi K, Saad F, Shore N, Sandhu S, Chi KN, Sartor O, Agarwal N, Olmos D, Thiery-Vuillemin A, Twardowski P, Roubaud G, Özgüroğlu M, Kang J, Burgents J, Gresty C, Corcoran C, Adelman CA, de Bono J and PROfound Trial Investigators: Survival with olaparib in metastatic castrationresistant prostate cancer. N Engl J Med 383(24): 2345-2357, 2020. PMID: 32955174. DOI: 10.1056/NEJMoa2022485

11 Stopsack KH: Efficacy of PARP inhibition in metastatic castration-resistant prostate cancer is very different with nonBRCA DNA repair alterations: Reconstructing prespecified endpoints for cohort B from the Phase 3 PROfound trial of olaparib. Eur Urol 79(4): 442-445, 2021. PMID: 33012578. DOI: $10.1016 /$ j.eururo.2020.09.024

12 Grewal K, Grewal K and Tabbara IA: PARP inhibitors in prostate cancer. Anticancer Res 41(2): 551-556, 2021. PMID: 33517260. DOI: 10.21873 /anticanres.14807

13 Lowrance WT, Breau RH, Chou R, Chapin BF, Crispino T, Dreicer R, Jarrard DF, Kibel AS, Morgan TM, Morgans AK, Oh WK, Resnick MJ, Zietman AL and Cookson MS: Advanced prostate cancer: AUA/ASTRO/SUO Guideline PART I. J Urol 205(1): 1421, 2021. PMID: 32960679. DOI: 10.1097/JU.0000000000001375

14 EAU Guidelines: Prostate Cancer I Uroweb. Available at: https://uroweb.org/guideline/prostate-cancer/\#6_5 [Last accessed on August 4, 2021]

15 Teyssonneau D, Margot H, Cabart M, Anonnay M, Sargos P, Vuong NS, Soubeyran I, Sevenet N and Roubaud G: Prostate cancer and PARP inhibitors: progress and challenges. J Hematol Oncol 14(1): 51, 2021. PMID: 33781305. DOI: 10.1186/s13045021-01061-x

16 Pritchard CC, Mateo J, Walsh MF, De Sarkar N, Abida W, Beltran H, Garofalo A, Gulati R, Carreira S, Eeles R, Elemento O, Rubin MA, Robinson D, Lonigro R, Hussain M, Chinnaiyan A, Vinson J, Filipenko J, Garraway L, Taplin ME, AlDubayan S, Han GC, Beightol M, Morrissey C, Nghiem B, Cheng HH, Montgomery B, Walsh T, Casadei S, Berger M, Zhang L, Zehir A, Vijai J, Scher HI, Sawyers C, Schultz N, Kantoff PW, Solit D, Robson M, Van Allen EM, Offit K, de Bono J and Nelson PS: Inherited DNA-repair gene mutations in men with metastatic prostate cancer. N Engl J Med 375(5): 443-453, 2016. PMID: 27433846. DOI: 10.1056/NEJMoa1603144

17 Holeckova K, Baluchova K, Hives M, Musak L, Kliment J Sr and Skerenova M: Germline mutations in DNA repair genes in patients with metastatic castration-resistant prostate cancer. In Vivo 34(4): 1773-1778, 2020. PMID: 32606146. DOI: 10.21873/invivo.11971

18 Ledet EM, Burgess EF, Sokolova AO, Jaeger EB, Hatton W, Moses M, Miller P, Cotogno P, Layton J, Barata P, Lewis BE, Nakazawa M, Zhu J, Dellinger B, Elrefai S, Nafissi NN, Egan JB, 
Shore N, McKay RR, Bryce AH, Cheng HH, Antonarakis ES and Sartor O: Comparison of germline mutations in African American and Caucasian men with metastatic prostate cancer. Prostate 81(7): 433-439, 2021. PMID: 33792945. DOI: 10.1002/pros.24123

19 Kwon DH, Borno HT, Cheng HH, Zhou AY and Small EJ: Ethnic disparities among men with prostate cancer undergoing germline testing. Urol Oncol 38(3): 80.e1-80.e7, 2020. PMID: 31630993. DOI: 10.1016/j.urolonc.2019.09.010

20 Robinson D, Van Allen EM, Wu YM, Schultz N, Lonigro RJ, Mosquera JM, Montgomery B, Taplin ME, Pritchard CC, Attard G, Beltran H, Abida W, Bradley RK, Vinson J, Cao X, Vats P, Kunju LP, Hussain M, Feng FY, Tomlins SA, Cooney KA, Smith DC, Brennan C, Siddiqui J, Mehra R, Chen Y, Rathkopf DE, Morris MJ, Solomon SB, Durack JC, Reuter VE, Gopalan A, Gao J, Loda M, Lis RT, Bowden M, Balk SP, Gaviola G, Sougnez C, Gupta M, Yu EY, Mostaghel EA, Cheng HH, Mulcahy H, True LD, Plymate SR, Dvinge H, Ferraldeschi R, Flohr P, Miranda S, Zafeiriou Z, Tunariu N, Mateo J, PerezLopez R, Demichelis F, Robinson BD, Schiffman M, Nanus DM, Tagawa ST, Sigaras A, Eng KW, Elemento O, Sboner A, Heath EI, Scher HI, Pienta KJ, Kantoff P, de Bono JS, Rubin MA, Nelson PS, Garraway LA, Sawyers CL and Chinnaiyan AM: Integrative clinical genomics of advanced prostate cancer. Cell 161(5): 1215-1228, 2015. PMID: 26000489. DOI: 10.1016/j.cell.2015.05.001

21 Mateo J, Carreira S, Sandhu S, Miranda S, Mossop H, PerezLopez R, Nava Rodrigues D, Robinson D, Omlin A, Tunariu N, Boysen G, Porta N, Flohr P, Gillman A, Figueiredo I, Paulding C, Seed G, Jain S, Ralph C, Protheroe A, Hussain S, Jones R, Elliott T, McGovern U, Bianchini D, Goodall J, Zafeiriou Z, Williamson CT, Ferraldeschi R, Riisnaes R, Ebbs B, Fowler G, Roda D, Yuan W, Wu YM, Cao X, Brough R, Pemberton H, A'Hern R, Swain A, Kunju LP, Eeles R, Attard G, Lord CJ, Ashworth A, Rubin MA, Knudsen KE, Feng FY, Chinnaiyan AM, Hall E and de Bono JS: DNA-repair defects and olaparib in metastatic prostate cancer. N Engl J Med 373(18): 1697-1708, 2015. PMID: 26510020. DOI: 10.1056/NEJMoa1506859

22 Castro E, Goh C, Olmos D, Saunders E, Leongamornlert D, Tymrakiewicz M, Mahmud N, Dadaev T, Govindasami K, Guy M, Sawyer E, Wilkinson R, Ardern-Jones A, Ellis S, Frost D, Peock S, Evans DG, Tischkowitz M, Cole T, Davidson R, Eccles D, Brewer C, Douglas F, Porteous ME, Donaldson A, Dorkins H, Izatt L, Cook J, Hodgson S, Kennedy MJ, Side LE, Eason J, Murray A, Antoniou AC, Easton DF, Kote-Jarai Z and Eeles R: Germline BRCA mutations are associated with higher risk of nodal involvement, distant metastasis, and poor survival outcomes in prostate cancer. J Clin Oncol 31(14): 1748-1757, 2013. PMID: 23569316. DOI: 10.1200/JCO.2012.43.1882

23 Tryggvadóttir L, Vidarsdóttir L, Thorgeirsson T, Jonasson JG, Olafsdóttir EJ, Olafsdóttir GH, Rafnar T, Thorlacius S, Jonsson E, Eyfjord JE and Tulinius H: Prostate cancer progression and survival in BRCA2 mutation carriers. J Natl Cancer Inst 99(12): 929-935, 2007. PMID: 17565157. DOI: 10.1093/jnci/djm005

24 Castro E, Goh C, Leongamornlert D, Saunders E, Tymrakiewicz M, Dadaev T, Govindasami K, Guy M, Ellis S, Frost D, Bancroft E, Cole T, Tischkowitz M, Kennedy MJ, Eason J, Brewer C, Evans DG, Davidson R, Eccles D, Porteous ME, Douglas F, Adlard J, Donaldson A, Antoniou AC, Kote-Jarai Z, Easton DF, Olmos D and Eeles R: Effect of BRCA mutations on metastatic relapse and cause-specific survival after radical treatment for localised prostate cancer. Eur Urol 68(2): 186-193, 2015. PMID: 25454609. DOI: $10.1016 /$ j.eururo.2014.10.022

25 Castro E, Romero-Laorden N, Del Pozo A, Lozano R, Medina A, Puente J, Piulats JM, Lorente D, Saez MI, Morales-Barrera R, Gonzalez-Billalabeitia E, Cendón Y, García-Carbonero I, Borrega P, Mendez Vidal MJ, Montesa A, Nombela P, Fernández-Parra E, Gonzalez Del Alba A, Villa-Guzmán JC, Ibáñez K, Rodriguez-Vida A, Magraner-Pardo L, PerezValderrama B, Vallespín E, Gallardo E, Vazquez S, Pritchard CC, Lapunzina P and Olmos D: PROREPAIR-B: A prospective cohort study of the impact of germline DNA repair mutations on the outcomes of patients with metastatic castration-resistant prostate cancer. J Clin Oncol 37(6): 490-503, 2019. PMID: 30625039. DOI: $10.1200 / J C O .18 .00358$

26 Annala M, Fu S, Bacon JVW, Sipola J, Iqbal N, Ferrario C, Ong M, Wadhwa D, Hotte SJ, Lo G, Tran B, Wood LA, Gingerich JR, North SA, Pezaro CJ, Ruether JD, Sridhar SS, Kallio HML, Khalaf DJ, Wong A, Beja K, Schönlau E, Taavitsainen S, Nykter M, Vandekerkhove G, Azad AA, Wyatt AW and Chi KN: Cabazitaxel versus abiraterone or enzalutamide in poor prognosis metastatic castration-resistant prostate cancer: a multicentre, randomised, open-label, phase II trial. Ann Oncol 32(7): 896-905, 2021. PMID: 33836265. DOI: 10.1016/j.annonc.2021.03.205

27 Mateo J, Cheng HH, Beltran H, Dolling D, Xu W, Pritchard CC, Mossop H, Rescigno P, Perez-Lopez R, Sailer V, Kolinsky M, Balasopoulou A, Bertan C, Nanus DM, Tagawa ST, Thorne H, Montgomery B, Carreira S, Sandhu S, Rubin MA, Nelson PS and de Bono JS: Clinical outcome of prostate cancer patients with germline DNA repair mutations: Retrospective analysis from an international study. Eur Urol 73(5): 687-693, 2018. PMID: 29429804. DOI: 10.1016/j.eururo.2018.01.010

28 Loriot Y, Bianchini D, Ileana E, Sandhu S, Patrikidou A, Pezaro C, Albiges L, Attard G, Fizazi K, De Bono JS and Massard C: Antitumour activity of abiraterone acetate against metastatic castration-resistant prostate cancer progressing after docetaxel and enzalutamide (MDV3100). Ann Oncol 24(7): 1807-1812, 2013. PMID: 23576708. DOI: 10.1093/annonc/mdt136

29 Miyake H, Hara T, Tamura K, Sugiyama T, Furuse H, Ozono S and Fujisawa M: Comparative assessment of efficacies between 2 alternative therapeutic sequences with novel androgen receptor-axis-targeted agents in patients with chemotherapynaïve metastatic castration-resistant prostate cancer. Clin Genitourin Cancer 15(4): e591-e597, 2017. PMID: 28063845. DOI: $10.1016 /$ j.clgc.2016.12.015

30 de Wit R, de Bono J, Sternberg CN, Fizazi K, Tombal B, Wülfing C, Kramer G, Eymard JC, Bamias A, Carles J, Iacovelli R, Melichar B, Sverrisdóttir Á, Theodore C, Feyerabend S, Helissey C, Ozatilgan A, Geffriaud-Ricouard C, Castellano D and CARD Investigators: Cabazitaxel versus abiraterone or enzalutamide in metastatic prostate cancer. N Engl J Med 381(26): 2506-2518, 2019. PMID: 31566937. DOI: 10.1056/NEJMoa1911206

31 Chi K, Hotte SJ, Joshua AM, North S, Wyatt AW, Collins LL and Saad F: Treatment of mCRPC in the AR-axis-targeted therapy-resistant state. Ann Oncol 26(10): 2044-2056, 2015. PMID: 26101426. DOI: 10.1093/annonc/mdv267

32 Alsop K, Fereday S, Meldrum C, deFazio A, Emmanuel C, George J, Dobrovic A, Birrer MJ, Webb PM, Stewart C, Friedlander M, Fox S, Bowtell D and Mitchell G: BRCA mutation frequency and patterns of treatment response in BRCA mutationpositive women with ovarian cancer: a report from the Australian 
Ovarian Cancer Study Group. J Clin Oncol 30(21): 2654-2663, 2012. PMID: 22711857. DOI: 10.1200/JCO.2011.39.8545

33 Gorodnova TV, Sokolenko AP, Ivantsov AO, Iyevleva AG, Suspitsin EN, Aleksakhina SN, Yanus GA, Togo AV, Maximov SY and Imyanitov EN: High response rates to neoadjuvant platinum-based therapy in ovarian cancer patients carrying germline BRCA mutation. Cancer Lett 369(2): 363-367, 2015. PMID: 26342406. DOI: 10.1016/j.canlet.2015.08.028

34 Vencken PMLH, Kriege M, Hoogwerf D, Beugelink S, van der Burg MEL, Hooning MJ, Berns EM, Jager A, Collée M, Burger CW and Seynaeve C: Chemosensitivity and outcome of BRCA1and BRCA2-associated ovarian cancer patients after first-line chemotherapy compared with sporadic ovarian cancer patients. Ann Oncol 22(6): 1346-1352, 2011. PMID: 21228333. DOI: 10.1093/annonc/mdq628

35 Palacio S, McMurry HS, Ali R, Donenberg T, Silva-Smith R, Wideroff G, Sussman DA, Rocha Lima CMS and Hosein PJ: DNA damage repair deficiency as a predictive biomarker for FOLFIRINOX efficacy in metastatic pancreatic cancer. J Gastrointest Oncol 10(6): 1133-1139, 2019. PMID: 31949930. DOI: $10.21037 /$ jgo.2019.09.12

36 Kasi A, Bajwa S, Al-jumayli M, Saeed A and Godwin A: Abstract B29: Outcomes of DNA repair-deficient pancreatic cancers: KU Cancer Center experience. Genetics and Genomics 79(24 Suppl), 2020. DOI: 10.1158/1538-7445.PANCA19-B29

37 Tutt A, Tovey H, Cheang MCU, Kernaghan S, Kilburn L, Gazinska P, Owen J, Abraham J, Barrett S, Barrett-Lee P, Brown R, Chan S, Dowsett M, Flanagan JM, Fox L, Grigoriadis A, Gutin A, Harper-Wynne C, Hatton MQ, Hoadley KA, Parikh J, Parker P, Perou CM, Roylance R, Shah V, Shaw A, Smith IE, Timms KM, Wardley AM, Wilson G, Gillett C, Lanchbury JS, Ashworth A, Rahman N, Harries M, Ellis P, Pinder SE and Bliss JM: Carboplatin in BRCA1/2-mutated and triple-negative breast cancer BRCAness subgroups: the TNT Trial. Nat Med 24(5): 628-637, 2018. PMID: 29713086. DOI: 10.1038/s41591-0180009-7

38 Canobbio L, Guarneri D, Miglietta L, Decensi A, Oneto F and Boccardo F: Carboplatin in advanced hormone refractory prostatic cancer patients. Eur J Cancer 29A(15): 2094-2096, 1993. PMID: 7507687. DOI: 10.1016/0959-8049(93)90040-m

$39 \mathrm{Oh}$ WK, Tay MH and Huang J: Is there a role for platinum chemotherapy in the treatment of patients with hormonerefractory prostate cancer? Cancer 109(3): 477-486, 2007. PMID: 17186531. DOI: $10.1002 /$ cncr.22439

40 Pomerantz MM, Spisák S, Jia L, Cronin AM, Csabai I, Ledet E, Sartor AO, Rainville I, O’Connor EP, Herbert ZT, Szállási Z, Oh WK, Kantoff PW, Garber JE, Schrag D, Kibel AS and Freedman ML: The association between germline BRCA2 variants and sensitivity to platinum-based chemotherapy among men with metastatic prostate cancer. Cancer 123(18): 3532-3539, 2017. PMID: 28608931. DOI: 10.1002/cncr.30808

41 Schmid S, Omlin A, Higano C, Sweeney C, Martinez Chanza N, Mehra N, Kuppen MCP, Beltran H, Conteduca V, Vargas Pivato de Almeida D, Cotait Maluf F, Oh WK, Tsao CK, Sartor O, Ledet E, Di Lorenzo G, Yip SM, Chi KN, Bianchini D, De Giorgi U, Hansen AR, Beer TM, Lavaud P, Morales-Barrera R, Tucci M, Castro E, Karalis K, Bergman AM, Le ML, ZürrerHärdi U, Pezaro C, Suzuki H, Zivi A, Klingbiel D, Schär S and Gillessen S: Activity of platinum-based chemotherapy in patients with advanced prostate cancer with and without DNA repair gene aberrations. JAMA Netw Open 3(10): e2021692, 2020. PMID: 33112397. DOI: 10.1001/jamanetworkopen.2020.21692

42 Mota JM, Barnett E, Nauseef JT, Nguyen B, Stopsack KH, Wibmer A, Flynn JR, Heller G, Danila DC, Rathkopf D, Slovin S, Kantoff PW, Scher HI, Morris MJ, Schultz N, Solit DB and Abida W: Platinum-based chemotherapy in metastatic prostate cancer with DNA repair gene alterations. JCO Precis Oncol 4: 355-366, 2020. PMID: 32856010. DOI: 10.1200/po.19.00346

43 Slootbeek PHJ, Duizer ML, van der Doelen MJ, Kloots ISH, Kuppen MCP, Westgeest HM, Uyl-de Groot CA, Pamidimarri Naga S, Ligtenberg MJL, van Oort IM, Gerritsen WR, Schalken JA, Kroeze LI, Bloemendal HJ and Mehra N: Impact of DNA damage repair defects and aggressive variant features on response to carboplatin-based chemotherapy in metastatic castration-resistant prostate cancer. Int J Cancer 148(2): 385-395, 2021. PMID: 32965028. DOI: 10.1002/ijc.33306

44 Zafeiriou Z, Bianchini D, Chandler R, Rescigno P, Yuan W, Carreira S, Barrero M, Petremolo A, Miranda S, Riisnaes R, Rodrigues DN, Gurel B, Sumanasuriya S, Paschalis A, Sharp A, Mateo J, Tunariu N, Chinnaiyan AM, Pritchard CC, Kelly K and de Bono JS: Genomic analysis of three metastatic prostate cancer patients with exceptional responses to carboplatin indicating different types of DNA repair deficiency. Eur Urol 75(1): 184-192, 2019. PMID: 30340782. DOI: 10.1016/j.eururo. 2018.09.048

45 Cheng HH, Pritchard CC, Boyd T, Nelson PS and Montgomery B: Biallelic inactivation of BRCA2 in platinum-sensitive metastatic castration-resistant prostate cancer. Eur Urol 69(6): 992-995, 2016. PMID: 26724258. DOI: 10.1016/j.eururo.2015.11.022

46 Berchuck J, Silver R, Bakouny Z, Abou alaiwi S, Hamid A, Sweeney C, Freedman M, Pomerantz M and Taplin M: Response to olaparib or carboplatin in a real-world cohort of men with DNA damage repair (DDR) deficient metastatic castration-resistant prostate cancer (mCRPC). Journal of Clinical Oncology 38(6_suppl): 43-43, 2020. DOI: 10.1200/JCO.2020.38.6_suppl.43

47 Gallagher DJ, Cronin AM, Milowsky MI, Morris MJ, Bhatia J, Scardino PT, Eastham JA, Offit K and Robson ME: Germline BRCA mutation does not prevent response to taxane-based therapy for the treatment of castration-resistant prostate cancer. BJU Int 109(5): 713-719, 2012. PMID: 21756279. DOI: 10.1111/j.1464-410X.2011.10292.x

48 Ritter MA, Cleaver JE and Tobias CA: High-LET radiations induce a large proportion of non-rejoining DNA breaks. Nature 266(5603): 653-655, 1977. PMID: 859634. DOI: 10.1038/266653a0

49 van der Doelen MJ, Isaacsson Velho P, Slootbeek PHJ, Pamidimarri Naga S, Bormann M, van Helvert S, Kroeze LI, van Oort IM, Gerritsen WR, Antonarakis ES and Mehra N: Impact of DNA damage repair defects on response to radium-223 and overall survival in metastatic castration-resistant prostate cancer. Eur J Cancer 136: 16-24, 2020. PMID: 32634759. DOI: 10.1016/j.ejca.2020.05.001

50 Castro E, Mejorada R, Saez M, De Giorgi UFF, Aragón I, Laorden N, De Velasco Oria de Rueda GA, Magraner L, Pacheco MI, Puente J, González del Alba A, Garcia P, Conteduca V, Villa Guzman JC, Fernandez Parra E, Rodriguez-Vida A, Medina Colmenero A, Morales Barrera R, Lorente D and Olmos Hidalgo $\mathrm{D}$ : Impact of germline mutations in homologous recombination (HR) genes on the response to Radium-223 for metastatic castration resistant prostate cancer (mCRPC). Annals of Oncology 30: v343-v344, 2020. DOI: 10.1093/annonc/mdz248.033 
51 Tan DS and Kaye SB: Chemotherapy for patients with BRCA1 and BRCA2-mutated ovarian cancer: same or different? Am Soc Clin Oncol Educ Book: 114-121, 2015. PMID: 25993149. DOI: 10.14694/EdBook_AM.2015.35.114

52 Lips EH, Benard-Slagter A, Opdam M, Scheerman CE, Wesseling J, Hogervorst FBL, Linn SC, Savola S and Nederlof PM: BRCAness digitalMLPA profiling predicts benefit of intensified platinum-based chemotherapy in triple-negative and luminal-type breast cancer. Breast Cancer Res 22(1): 79, 2020. PMID: 32711554. DOI: 10.1186/s13058-020-01313-7

53 Mirza MR, Monk BJ, Herrstedt J, Oza AM, Mahner S, Redondo A, Fabbro M, Ledermann JA, Lorusso D, Vergote I, Ben-Baruch NE, Marth C, Mądry R, Christensen RD, Berek JS, Dørum A, Tinker AV, du Bois A, González-Martín A, Follana P, Benigno B, Rosenberg P, Gilbert L, Rimel BJ, Buscema J, Balser JP, Agarwal S, Matulonis UA and ENGOT-OV16/NOVA Investigators: Niraparib maintenance therapy in platinumsensitive, recurrent ovarian cancer. N Engl J Med 375(22): 21542164, 2016. PMID: 27717299. DOI: 10.1056/NEJMoa 1611310

54 Poveda A, Floquet A, Ledermann JA, Asher R, Penson RT, Oza AM, Korach J, Huzarski T, Pignata S, Friedlander M, Baldoni A, Park-Simon TW, Tamura K, Sonke GS, Lisyanskaya A, Kim JH, Filho EA, Milenkova T, Lowe ES, Rowe P, Vergote I, Pujade-Lauraine E and SOLO2/ENGOT-Ov21 investigators: Olaparib tablets as maintenance therapy in patients with platinum-sensitive relapsed ovarian cancer and a BRCA1/2 mutation (SOLO2/ENGOT-Ov21): a final analysis of a doubleblind, randomised, placebo-controlled, phase 3 trial. Lancet Oncol 22(5): 620-631, 2021. PMID: 33743851. DOI: 10.1016/ S1470-2045(21)00073-5
55 Golan T, Hammel P, Reni M, Van Cutsem E, Macarulla T, Hall MJ, Park JO, Hochhauser D, Arnold D, Oh DY, ReinacherSchick A, Tortora G, Algül H, O'Reilly EM, McGuinness D, Cui KY, Schlienger K, Locker GY and Kindler HL: Maintenance olaparib for germline BRCA-mutated metastatic pancreatic cancer. N Engl J Med 381(4): 317-327, 2019. PMID: 31157963. DOI: $10.1056 /$ NEJMoa1903387

56 Fong PC, Yap TA, Boss DS, Carden CP, Mergui-Roelvink M, Gourley C, De Greve J, Lubinski J, Shanley S, Messiou C, A'Hern R, Tutt A, Ashworth A, Stone J, Carmichael J, Schellens JH, de Bono JS and Kaye SB: Poly(ADP)-ribose polymerase inhibition: frequent durable responses in BRCA carrier ovarian cancer correlating with platinum-free interval. J Clin Oncol 28(15): 2512-2519, 2010. PMID: 20406929. DOI: 10.1200/ JCO.2009.26.9589

57 Maughan BL and Antonarakis ES: Olaparib and rucaparib for the treatment of DNA repair-deficient metastatic castrationresistant prostate cancer. Expert Opin Pharmacother: 1-8, 2021. PMID: 33827356. DOI: 10.1080/14656566.2021.1912015
Received July 23, 2021

Revised August 5, 2021

Accepted August 9, 2021 